\title{
The effect of insecticide application by dropleg sprayers on pollen beetle parasitism in oilseed rape
}

\author{
Johannes Hausmann (D) Udo Heimbach • Michael Rostás • Meike Brandes
}

Received: 22 January 2021/Accepted: 20 August 2021/Published online: 2 September 2021

(C) The Author(s) 2021

\begin{abstract}
Dropleg sprayers apply pesticides below the flower horizon of oilseed rape plants and thus reduce unwanted side effects on pollinating insects. Whether this technique benefits parasitoids of seed and pollen feeding insect pests has not been studied earlier. To answer this question, we first assessed the vertical distribution of pests and parasitoids using a portable aspirator. In addition, parasitism rates of pollen beetle, Brassicogethes aeneus Fabricius (Coleoptera: Nitidulidae), by the larval parasitoid Tersilochus heterocerus Thomson (Hymenoptera: Ichneumonidae) were compared in conventional and dropleg sprayed fields over four years (2016-2019), using the neonicotinoids thiacloprid and acetamiprid. Our results show that seed and pollen feeders were
\end{abstract}

Handling Editor: Dirk Babendreier.

Supplementary Information The online version contains supplementary material available at https://doi.org/10.1007/ s10526-021-10111-9.

J. Hausmann ( $₫)$ · U. Heimbach · M. Brandes Institute for Plant Protection in Field Crops and Grassland, Julius Kühn-Institute (JKI), Federal Research Centre for Cultivated Plants, Messeweg 11-12, 38104 Braunschweig, Germany

e-mail: johannes.hausmann@julius-kuehn.de

M. Rostás

Division of Agricultural Entomology, Department of Crop Sciences, University of Göttingen, Grisebachstraße 6, 37077 Göttingen, Germany mainly found in the flowering canopy, while the predominant location of parasitoids was speciesspecific. Among pollen beetle parasitoids, Phradis interstitialis Thomson (Hymenoptera: Ichneumonidae) was more abundant below flowering canopy (63\% of total catch), whereas $T$. heterocerus was mainly caught in the flowering canopy (84\% of total catch). In the spraying experiments, average parasitism rates of pollen beetles by $T$. heterocerus ranged between 55 and $82 \%$ in the untreated controls. In the dropleg spray treatments, parasitism rates did not differ significantly from control levels, with the exception of thiacloprid application in 2019. In contrast, conventional spray applications resulted in a reduction of parasitism rates by up to $37 \%$ compared to the control for at least one of the insecticides in three out of four years. The impact of conventional application differed between years, which may be explained by the temporal coincidence between spray application and the immigration of parasitoids into the crop. We conclude that dropleg spraying exerts lower non-target effects on the main biological control agent of pollen beetle.

Keywords Tersilochus heterocerus .

Brassicogethes aeneus · Dropleg technique · Biological control 


\section{Introduction}

Due to concerns about declining insect populations in agricultural landscapes (Beckmann et al. 2019; Habel et al. 2016; Hallmann et al. 2017), there is considerable public and political will within the European Union to reduce pesticide applications and to improve integrated pest management strategies (European Commission 2020; Hatt and Osawa 2019). In this context, biological pest control by naturally occurring parasitoids and predators is an important ecosystem service that could possibly be enhanced by new application techniques such as dropleg sprayers. Droplegs are prolonged elastic nozzle holders that hang freely floating underneath the boom of the sprayer. Depending on the nozzle setting, the spray is directed towards the ground and sideways but avoids spraying the crop canopy. This technique was initially developed to improve fungicide applications in the lower vegetation layers of vegetables (Basil 2002; Rüegg and Total 2013). Searching for new applications, its use in flowering oilseed rape, Brassica napus L. (OSR), is under discussion. OSR is regularly treated with fungicides and insecticides during the period of flowering to prevent yield losses by the pathogen Sclerotinia sclerotiorum (Lib.) de Bary and by seed damaging insects like cabbage seedpod weevil, $\mathrm{Ceu}$ torhynchus obstrictus Marsham (Coleoptera: Curculionidae), or brassica pod midge, Dasineura brassicae Winnertz (Diptera: Cecidomyiidae). The active substances used for these applications reflect the most frequent residues found in honey (Karise et al. 2017) and bee bread (Rosenkranz et al. 2019), since OSR is an important forage crop for honeybees and other pollinators such as bumble bees or solitary wild bees (Garratt et al. 2014; Hayter and Cresswell 2006; van Reeth et al. 2018; Westphal et al. 2003, 2009). In flowering OSR, below-canopy spraying with droplegs avoids direct exposure of pollinators with pesticides in the field. Dropleg application was also shown to decrease the level of pesticide residues of systemic and non-systemic compounds in nectar and pollen, because flowers are left unsprayed (Wallner 2014, 2015). These findings have been the main selling point for promoting the new technique in OSR. Field studies have also shown that the control of the pathogen S. sclerotiorum is not affected by the type of application technique (Dicke 2018; Weimar-Bosse et al. 2017). However, the efficacy of insecticides applied with dropleg technique against the seed damaging insect pests is slightly reduced (Hausmann et al. 2019).

In addition to pollinators, parasitoids are another important insect guild in OSR, as they contribute considerably to the biological control of pests (Abram et al. 2019; Kovács et al. 2019; Ulber et al. 2010b; Veromann et al. 2010). Hence, the question arose whether applying systemic neonicotinoid insecticides to the lower vegetation layers using dropleg sprayers (Hausmann et al. 2019) could target pests in the OSR canopy, while having no or reduced impact on their co-occurring parasitoids. Many parasitoids are abundant in the crop during the flowering period (Nissen 1997; Ulber et al. 2010a) and insecticide application in this period can have detrimental effects on the parasitism rates of OSR pests such as cabbage seedpod weevil (Murchie et al. 1997) or pollen beetle, Brassicogethes aeneus Fabricius (Coleoptera: Nitidulidae) (Jansen 2017; Neumann 2010). To estimate whether dropleg spraying avoids such detrimental effects on parasitoids, it is important to determine their vertical distribution in the crop. Beneficial effects of dropleg can be expected with those parasitoids that are predominantly in the flower canopy where they may not be exposed to pesticides. The first objective of this work was therefore to assess the vertical distribution of several pest species of OSR reproductive parts and their parasitoids in the different vegetation layers of the crop during flowering.

Based on these observations, the second objective of this study was to elucidate whether dropleg spraying could potentially benefit the biological control of pollen beetle by reducing non-target effects on its larval parasitoids. Adults of B. aeneus damage the buds of OSR and are the major pest during the green bud stage (Alford et al. 2003). The larvae develop inside the bud and drop to the ground for pupation after one month (Williams 2010). Since pollen beetles have developed widespread resistance against the insecticidal class of pyrethroids (Heimbach and Müller 2013), and are also less sensitive to neonicotinoids (IRAC 2019) chemical control options for farmers in Germany and other European countries have become more and more restricted, while biological control is gaining in importance. The most relevant and widespread parasitoids of the pollen beetle in winter OSR in Germany are Tersilochus heterocerus Thomson (Hymenoptera: Ichneumonidae) and P. interstitialis 
Thomson (Hymenoptera: Ichneumonidae) (Ulber et al. 2010b). Both species are univoltine, koinobiont endoparasitoids of the larvae. The adults of these parasitoids overwinter in their pupal cocoons in the soil and, after emergence in spring, migrate to the current year's OSR fields (Nilsson 2003). Phradis interstitialis often colonizes the crop in the bud stage of the plants. The arrival of $T$. heterocerus occurs 1-2 weeks later and coincides with the beginning of flowering. Female parasitoids are already sexually mature at this time and no maturation feeding is necessary (Nilsson 2003). However, at least T. heterocerus is known to feed on nectar during the flowering period of OSR (Rusch et al. 2013). This parasitoid species could be beneficial if neonicotinoids applied during this time are not ingested in high concentration with this food resource. Both parasitoid species differ in their temporal abundance, their host finding behaviour and their host stage preferences, indicating niche separation between species (Berger et al. 2015). Field experiments were conducted over a four-year period, comparing the effects of two systemic insecticides on pollen beetle parasitism by T. heterocerus, when applied conventionally or by dropleg technique. Our investigations ultimately focused on this species as, in contrast to $P$. interstitialis, $T$. heterocerus was the dominating parasitoid of pollen beetle that was mainly present in the flowering canopy. The strongest effect of dropleg application was therefore expected for this species.

With this work we provide further insight into the vertical distribution of pests and parasitoids in OSR crops and first evidence regarding the effects of dropleg spraying on the biological control of pollen beetle. Our results show that parasitism rates in dropleg sprayed fields were generally as high as in unsprayed control fields, or at least higher than in the conventional spray treatment, suggesting a potential benefit of this novel application technique for biological control under certain conditions.

\section{Materials and methods}

Field sites

Experiments were conducted in 2016-2019 in four conventionally managed OSR fields near Braunschweig, Germany $\left(52^{\circ} 19^{\prime} 36.89^{\prime \prime} \mathrm{N}, 10^{\circ} 38^{\prime} 2.91^{\prime \prime}\right.$
E). Meteorological data of the site were obtained from the $5 \mathrm{~km}$ distant weather station Braunschweig Flughafen of the Deutscher Wetterdienst (Fig. 1). A different field was used each year with field areas of 3.3 ha in 2016-2018 and 24 ha in 2019. The vertical distribution of insect pests and their parasitoids was studied in the years 2018 and 2019. Sampling was carried out in the same OSR field used for the dropleg spraying trial, but adjacent to the treated area (Supplementary Figure S1). As the damage threshold for pollen beetles ( $>$ ten beetles per main shoot in the bud stage) was exceeded in 2018 and 2019 the whole OSR crop was treated with contact insecticides Avaunt (a.i.: $25.5 \mathrm{~g} \mathrm{ha}^{-1}$ indoxacarb) and Trebon 30 EC (a.i.: $57.7 \mathrm{~g} \mathrm{ha}^{-1}$ etofenprox) on 11th April 2018 and 1st April 2019, respectively. The applications reflect common agricultural practice and were indispensable to ensure an undamaged development of the inflorescences. OSR is growing very rapidly from the bud stage (plant height of approx. $50 \mathrm{~cm}$ ) to its final height $(1.2-1.5 \mathrm{~m})$ and all new plant tissues should be free of insecticide residues. Sampling for the assessments of the vertical distribution started 13 days after overall insecticide application (DAA) in 2018 and 7 DAA in 2019. However, in 2019 parasitoid immigration was not observed until 21 days after application. Thus, an influence of insecticide residues on the vertical distribution of insects at this time is unlikely but cannot be ruled out entirely.

Assessment of the vertical distribution of insects

Insects were sampled from the end of bud stage to the beginning of pod stage [BBCH 58-72, (Lancashire et al. 1991)]. In 2018, insects were collected on 13 sampling dates between 24th April (BBCH 59/60) and 17th May (BBCH 72) and in 2019 on 15 sampling dates between 8th April (BBCH 58) and 30th May (BBCH 72). All assessments were carried out in dry or dewy crop stands as frequently as possible, thereby focussing on the main flowering period. Timing of the sampling was flexible to cover any diurnal patterns.

Suction sampling was conducted by using a modified leaf vacuum sampler (STIHL SH 85C, nominal maximum air flow rate: $625 \mathrm{~m}^{3} \mathrm{~h}^{-1}$; diameter of the aspiration port: $20 \mathrm{~cm}$ ). Insects were collected at two different heights, namely in the "flowering canopy" and "below canopy". In the treatment "flowering canopy", the aspiration port was guided at a slow 


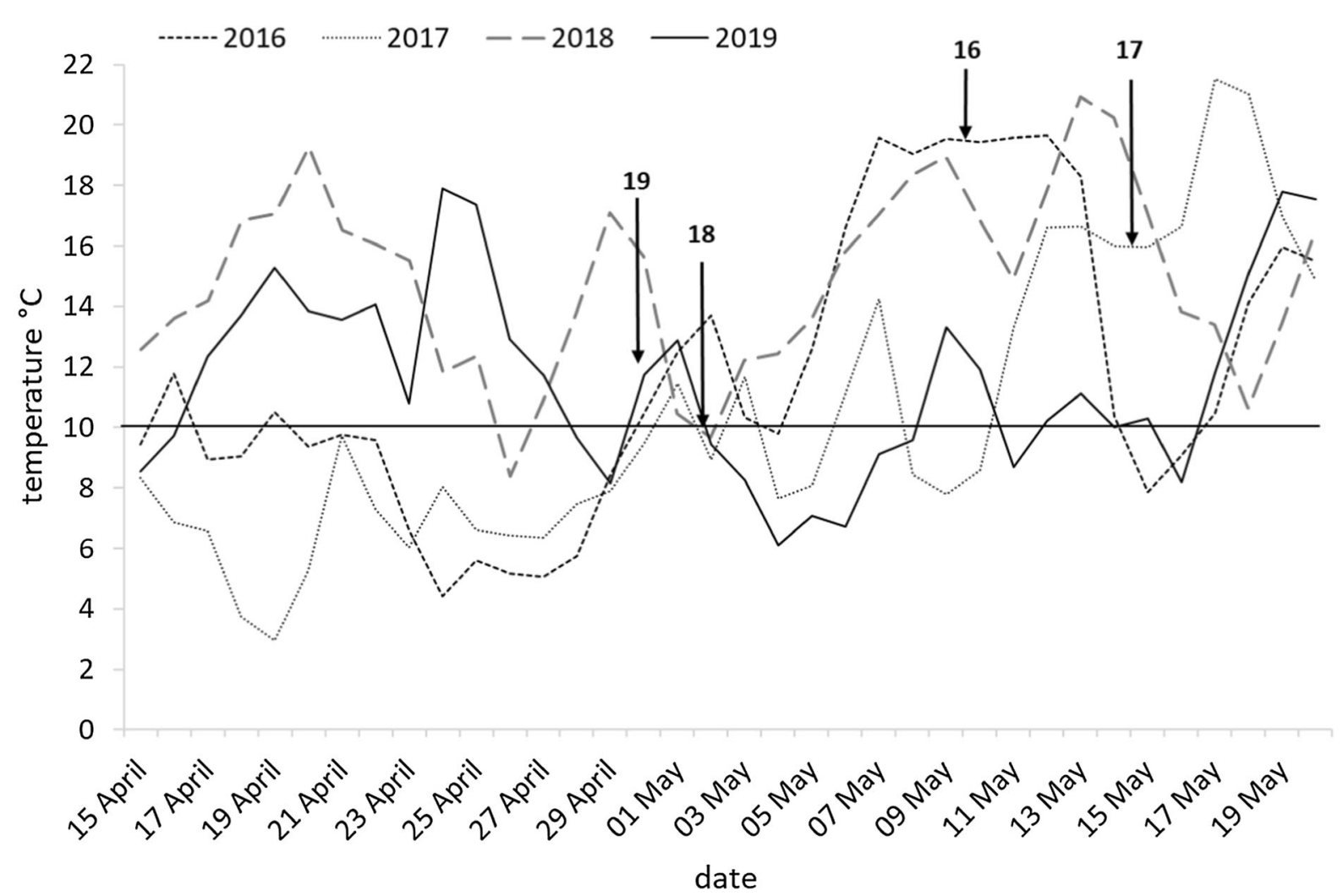

Fig. 1 Average daily temperatures $\left({ }^{\circ} \mathrm{C}\right)$ from 15 th April to 20 th May in the years 2016-2019. The arrows indicate the date of insecticide applications in the dropleg spraying trial in the

walking pace through the upper layer of flowers and buds along a $5 \mathrm{~m}$ transect. In the topmost layer, the port was held almost horizontally and orthogonal to the direction of movement at a distance of approximately $1 \mathrm{~m}$ from the experimenter's body. In the treatment "below canopy", suction samples were collected from stems and leaves at $30 \mathrm{~cm}$ below the flowering canopy including buds, flowers and pods. In this case, the aspiration port was held approximately $1 \mathrm{~m}$ in front of the experimenter's body in the direction of movement. This was done to prevent catching any insects that respond to vibrations by dropping from buds and flowers. One sample each from the flowering canopy and the below flowering canopy was taken from two adjacent $5 \mathrm{~m}$ transects. This was repeated at four randomly selected locations in the field at each sampling date. All field samples were taken by the same person to minimize individual variability. Since OSR branches out during pod set, small pathways through the field (width $0.5 \mathrm{~m}$, treated with glyphosate at the beginning of vegetation period) specific year. The horizontal line indicates the basic temperature for flight activity of $T$. heterocerus. Data source: Deutscher wetterdienst, station: Braunschweig flughafen

and tramlines (pathways used by machines) through the OSR field were used for sampling. A minimum distance of $25 \mathrm{~m}$ from the field border and $6 \mathrm{~m}$ from the dropleg trial area was adhered. Insect samples were collected in linen bags and then frozen at $-20{ }^{\circ} \mathrm{C}$. The frozen insects were separated from petals and plant material, counted and stored in $70 \%$ ethanol. All insect pests of OSR, as well as their key parasitoids, were identified at species level using keys by Ferguson et al. (2010), Vidal (2003) and in addition Muller et al. (2007) for the chalcid wasps. Regarding the species $T$. heterocerus and $P$. interstitialis, only the females were identified. This had ecological reasons, since males are abundant at high densities especially at the field borders and only the females are important for larval parasitism. Moreover, it is not trivial to identify males at species level. 
Field trials comparing effects of conventional and dropleg spraying

The trials were designed in a completely randomized block design with four replicates and five different treatments, including an untreated control. The distance between plots was $1 \mathrm{~m}$ (Table 1 , for further information see also Hausmann et al. 2019). Insecticides were applied once per year at full flowering, using both conventional spraying and dropleg spraying technique (Lechler 2020). Biscaya (a.i.: $72 \mathrm{~g}$ thiacloprid $\mathrm{ha}^{-1}$, Bayer Crop Science) was applied in each year, while Mospilan SG (a.i.: $40 \mathrm{~g}$ acetamiprid $\mathrm{ha}^{-1}$, FMC Agricultural Solutions) was sprayed in the years 2016 and 2017 and Mospilan SL (a.i.: $42 \mathrm{~g}$ acetamiprid $\mathrm{ha}^{-1}$, FMC Agricultural Solutions) in 2018 and 2019. Both active ingredients are neonicotinoids (IRAC 2020) and have systemic properties. The rest of the field was not treated with insecticides in the flowering period.

The larvae of pollen beetles were collected using six white water trays per plot (Backs, Rehbuck, $60 \times 10 \times 10 \mathrm{~cm}$ ) placed on the ground between the plant rows in the centre of each plot, $1 \mathrm{~h}$ before insecticide application. The trays were filled with a $10 \%(\mathrm{w} / \mathrm{v})$ solution of sodium benzoate in water and were emptied weekly, beginning one day after the application until the end of June (BBCH 80). Pollen beetle larvae were counted and stored in $70 \%$ ethanol at plot level. To determine parasitisation by $T$. heterocerus, the larvae were dissected and examined for parasitoid eggs (see Brandes et al. 2018, and
Hausmann et al. 2019). The number of larvae examined varied between years and sampling dates within a year (Supplementary Table S1). Parasitism by $T$. heterocerus was chosen because it is the most abundant parasitoid of $B$. aeneus in the area of Braunschweig (Brandes et al. 2018; Ulber et al. 2010b). In the year 2016, 160 larvae per treatment and sampling date were assessed. Due to low levels of pollen beetle infestation in 2017 larval numbers ranging between 229 and 527 individuals per treatment were pooled over three sampling dates. In 2018 and 2019 at least 200 larvae per treatment were assessed for each sampling date.

\section{Statistical analysis}

All statistical analyses were performed using $\mathrm{R}$ (version 3.6.1) (R Core Team 2019) in the graphical user interface $\mathrm{R}$ Studio. The vertical distribution of insect pests and their parasitoids in the crop layer is presented as stacked bar plot based on the counts of each species over all sampling dates and years in the flowering canopy and the below flowering canopy. Independence of the pest species observations and crop layer was tested using a $\chi^{2}$ test. For the parasitoid species observations Fisher's exact test was used to test independence from crop layer.

The parasitism rates of pollen beetle larvae by $T$. heterocerus were analysed separately for each year, because our aim was to present differences between insecticide treatments but not differences between years. A generalized linear model (GLM) explaining

Table 1 Design of the dropleg trials from 2016 to 2019 with applied insecticides, application dates and crop growth stages

\begin{tabular}{|c|c|c|c|c|}
\hline & 2016 & 2017 & 2018 & 2019 \\
\hline Trial design & \multicolumn{4}{|c|}{ Randomized complete block design (RCBD), 4 replicates } \\
\hline \multirow[t]{5}{*}{ Treatments } & \multicolumn{4}{|l|}{ Untreated control } \\
\hline & \multicolumn{4}{|c|}{ Conventional Biscaya } \\
\hline & \multicolumn{2}{|c|}{ Conventional Mospilan SG } & \multicolumn{2}{|c|}{ Conventional Mospilan SL } \\
\hline & \multicolumn{4}{|l|}{ Dropleg Biscaya } \\
\hline & \multicolumn{2}{|c|}{ Dropleg Mospilan SG } & \multicolumn{2}{|c|}{ Dropleg Mospilan SL } \\
\hline Date of application & $10 / 05 / 2016$ & $15 / 05 / 2017$ & $02 / 05 / 2018$ & $30 / 04 / 2019$ \\
\hline Growth stage & 65 & $65-67$ & 64 & 65 \\
\hline Plot size $\left(\mathrm{m}^{2}\right)$ & $240(12 \times 20 \mathrm{~m})$ & $300(12 \times 25 \mathrm{~m})$ & $240(12 \times 20 \mathrm{~m})$ & $540(27 \times 20 \mathrm{~m})$ \\
\hline
\end{tabular}

Insecticides were applied at a driving speed of $7 \mathrm{~km} \mathrm{~h}^{-1}$ with $3001 \mathrm{ha}^{-1}$ water. Weather was clear and wind speed was about $1.5-2.2 \mathrm{~m} \mathrm{~s}^{-1}$ except from $2016\left(3.4-3.9 \mathrm{~m} \mathrm{~s}^{-1}\right)$. All insecticides were applied at recommended field rates 
the parasitism rate of pollen beetle larvae by the treatment, the sampling date, the interaction between treatment and sampling date and the block was fitted using a logit link function. A binomial error distribution was assumed and models were tested for overdispersion. The full model including all variables and interactions was systematically compared with the reduced models via the AICc. The model with the lowest AICc value was chosen as it indicates the best fit (Burnham and Anderson 2002). The effect of different variables by was tested with an ANOVA. For model diagnostics the residuals were plotted against the predicted values and the explanatory variables. If some of the variables showed significance, a post-hoc analysis was done by performing a Tukey test at an $\alpha$ level of 0.05 using the package emmeans (Lenth et al. 2018). The R-script for the parasitism data is available on demand. Figures were created using the package ggplot2 (Wickham 2016). Regression lines were generated using the loess (locally estimated scatterplot smoothing) method implemented in the package.

\section{Results}

Vertical distribution of pests and parasitoids in the crop

Results on the vertical distribution of cabbage seedpod weevil (C. obstrictus), brassica pod midge (D. brassicae) and pollen beetle (B. aeneus) are shown as stacked bar plot (Fig. 2a). The location of the three pest species in the crop was not independent from the crop layer $\left(\chi^{2}=53.53, d f=2, p<0.001\right)$. Dasineura brassicae and $C$. obstrictus were mainly found in the flowering canopy. Brassicogethes aeneus was caught most frequently and was present only in $68 \%$ of catches in the flowering canopy. Compared to $C$. obstrictus and D. brassicae, B. aeneus was found significantly more often below the flowering canopy.

Different parasitoid species were detected during the flowering period in OSR (Fig. 2b). The pollen beetle parasitoid, $T$. heterocerus, was the most abundant species. Females of this parasitoid were mainly found in the flowering canopy of the crop. Only $16 \%$ of all specimen collected were observed below flowering canopy. The second key parasitoid of the pollen beetle, $P$. interstitialis, was less abundant and occurred predominantly below flowering canopy $(63 \%)$. Three larval parasitoid species of the cabbage seed weevil $C$. obstrictus were caught by suction sampling. These were, in decreasing order, Trichomalus perfectus Walker, Mesopolobus morys Walker and Stenomalina gracilis Walker (Hymenoptera: Pteromalidae). Trichmalus perfectus was disproportionately more frequent below canopy, whereas $M$. morys was found almost exclusively in the flowering canopy. The tersilochine parasitoids of stem weevils ( $\mathrm{Ceu}$ torhynchus pallidactylus Marsham and Ceutorhynchus napi Gyllenhaal, Coleoptera: Curculionidae) could not be identified at species level. They were mostly sampled in the vegetation layer below the flowering canopy of the crop. The distribution of the parasitoid species sampled was not independent from the crop layer $(p<0.001$, Fisher's exact test).

Temporal abundance of pollen beetle parasitoids

In 2018, monitoring was initiated at the end of bud stage (BBCH 59) on 24th April. At this time, immigration of parasitoids had already started as $P$. interstitialis and $T$. heterocerus were caught on the first sampling date (Fig. 3). In 2019, the development of inflorescences was earlier and sampling started at the end of bud stage (BBCH 58) in the second week of April. First females of $P$. interstitialis were caught below flowering canopy on the 22nd April at the beginning of flowering (BBCH 62). The first females of $T$. heterocerus were trapped three days later when the crop had reached almost the full flowering stage (BBCH 64). The main period of activity for $T$. heterocerus was at full flowering in 2018, and in this year $93 \%$ of all individuals were found in the flowering canopy. By contrast, only $64 \%$ of all $T$. heterocerus specimen were present in the flowering canopy in the following year. The abundance was lower and the period of activity was about one month, without a clear peak. P. interstitialis was less numerous in both years and occurred during the whole 
(a)

Brassicogethes aeneus
Ceutorynchus obstrictus

Dasineura brassicae

(b)

\author{
Phradis interstitialis \\ Mesopolobus morys \\ Stenomalina gracilis
}

Tersilochus heterocerus

Tersilochus spp.

Trichomalus perfectus below canopy flower canopy

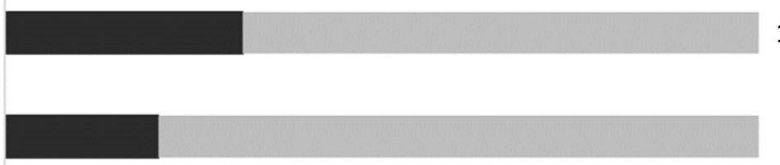

1200

200

1120

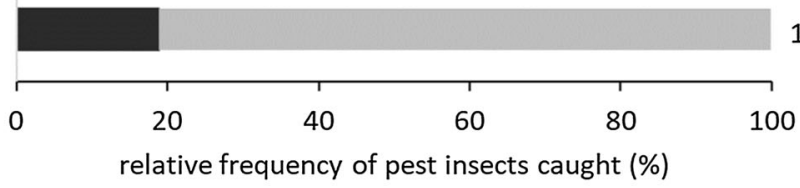

below canopy flower canopy

N

193

41

8

690

84

201

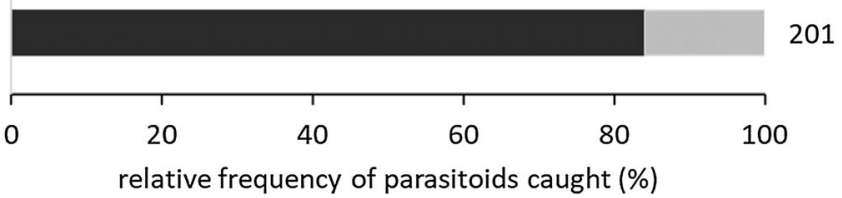

Fig. 2 Vertical distribution of $\mathbf{a}$ insect pests and $\mathbf{b}$ parasitoids of insect pests in oilseed rape, sampled with a portable aspirator during the flowering period in 2018 and 2019. Bars show the

sampling period in both years. Figures about the temporal abundance of the pest species can be found in the Supplementary Fig. S2.

Parasitism of pollen beetle larvae in field trials using dropleg technique

The average density of pollen beetle larvae dropping to the ground for pupation was lowest in 2017 $\left(443 \pm\right.$ SE 44 larvae $\mathrm{m}^{-2}$ ) and increased up to 6857 ( \pm 648 ) larvae $\mathrm{m}^{-2}$ in 2019 . The number of larvae per relative frequencies of species in the flowering/below flowering canopy. $\mathrm{N}$ the total number of individuals caught during the two seasons

$\mathrm{m}^{2}$ varied between the different blocks within a given year. Number of larvae in the untreated control plots was not correlated with $T$. heterocerus parasitism rates in these plots ( $r=-0.15, d f=14, p=0.578)$.

The parasitism rate of pollen beetle larvae by $T$. heterocerus in the untreated control increased from $56 \%( \pm 3 \%)$ in the year 2016 up to $82 \%( \pm 1 \%)$ in 2018 and fell back to $55 \%( \pm 2 \%$ ) in 2019 (Fig. 4). The effects of treatments differed within the years 2017 $\left(\chi^{2}=19.71, d f=4, p=0.0006\right), 2018\left(F_{4,149}=3.49\right.$, $p=0.0093)$ and $2019\left(F_{4,87}=48.34, p<0.0001\right)$. In 
(a)

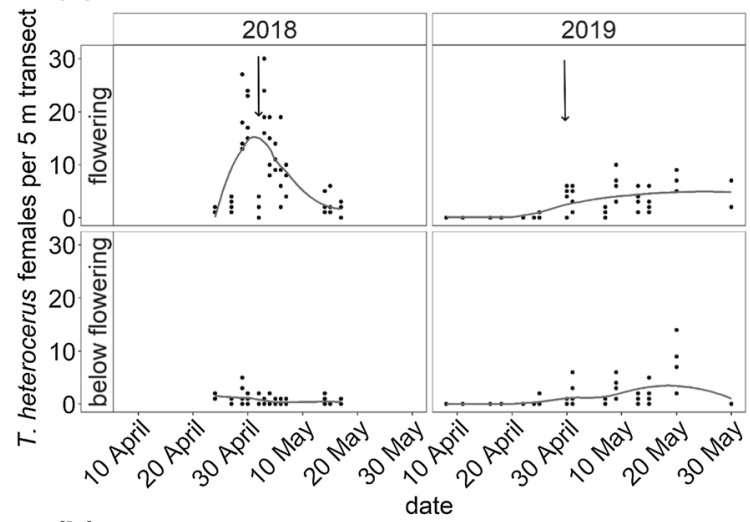

(b)

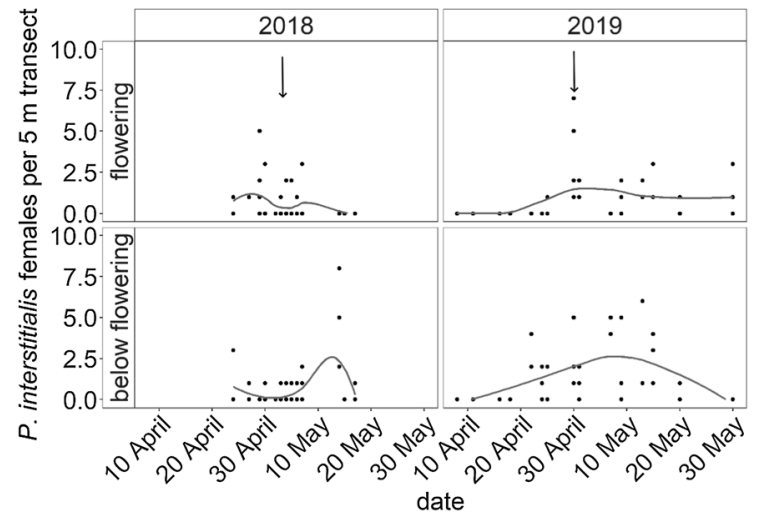

Fig. 3 Number of individuals (dots) sampled with an aspiration trap on a $5 \mathrm{~m}$ transect of $\mathbf{a} T$. heterocerus and $\mathbf{b} P$. interstitialis females in the flowering canopy and below flowering canopy of oilseed rape at different sampling dates during the period of flowering in 2018 and 2019. Curves are corresponding to loess regression lines. Arrows correspond to the dates of insecticide application in the adjacent dropleg spraying trial

all years, parasitism rates by $T$. heterocerus in the dropleg Mospilan treatment was not significantly different from the control, while the dropleg Biscaya treatment showed a significantly lower parasitism rate only in $2019(44 \% \pm 2 \%, p=0.0054)$. In the years 2017-2019, lower parasitism rates were found in the conventional treatment compared to control and dropleg treatments. More specifically, conventional application of Biscaya significantly reduced parasitism rates in $2017(63 \% \pm 3 \%)$ compared to the control (parasitism rate $73 \% \pm 2 \%, p=0.0351)$ and the dropleg Biscaya treatment (parasitism rate $77 \% \pm 2 \%$, $p=0.0021)$. In 2019, the conventional application of Biscaya (parasitism rate $34 \% \pm 2 \%$ ) resulted in a significantly lower parasitism rate compared to the control (parasitism rate $55 \% \pm 2 \%, p<0.0001$ ) and both dropleg treatments (dropleg Biscaya $44 \% \pm 2 \%$, $p=0.0123$; dropleg Mospilan $52 \% \pm 2 \%$, $p<0.0001)$. The conventional Mospilan treatment significantly reduced the parasitism rate of pollen beetles in $2018(74 \% \pm 2 \%)$ in comparison to the control (parasitism rate $82 \% \pm 1 \%, p=0.0069$ ) and the dropleg Mospilan treatment (parasitism rate $81 \% \pm 3 \%, p=0.0288)$. The same was found in 2019 with $37 \% \pm 2 \%$ parasitism in conventional Mospilan treatment (control $p<0.0001$; dropleg Mospilan $p<0.0001$ ). Results on average parasitism rates and multiparasitism by Phradis in four years of field trials are presented in the Supplementary Table S2.

\section{Discussion}

After insecticide application by using dropleg technique the flowering canopy of the crop is left unsprayed and the residue levels of the pesticide in nectar and pollen are relatively low compared to conventional spray application (Wallner 2014; Weimar-Bosse et al. 2017). In our study, we tested whether dropleg technique is suitable to avoid non-target effects on parasitoids. Therefore, the vertical distribution of insect pests and parasitoids was studied during the flowering period of OSR. Our results demonstrate that both the seed damaging pest insects C. obstrictus and D. brassicae, as well as the bud damaging beetle $B$. aeneus, are active predominately in the flowering canopy (Fig. 2a). The latter was the most frequent insect pest in our study (55\% of all insect pest catches) and was partially found below canopy ( $32 \%$ of all pollen beetle catches). This might be explained because females of $B$. aeneus feed on pollen and lay their eggs in medium sized, closed buds of OSR (Hervé et al. 2015). In OSR the main raceme is the first to produce flowers (Tayo and Morgan 1975). At this growth stage (BBCH 61-65), the side branches are still at a lower height and in the bud stage, which renders them suitable for oviposition and might attract B. aeneus beetles (Supplementary Figure S2).

The parasitoid species of OSR herbivores found in our study differed significantly in their vertical 


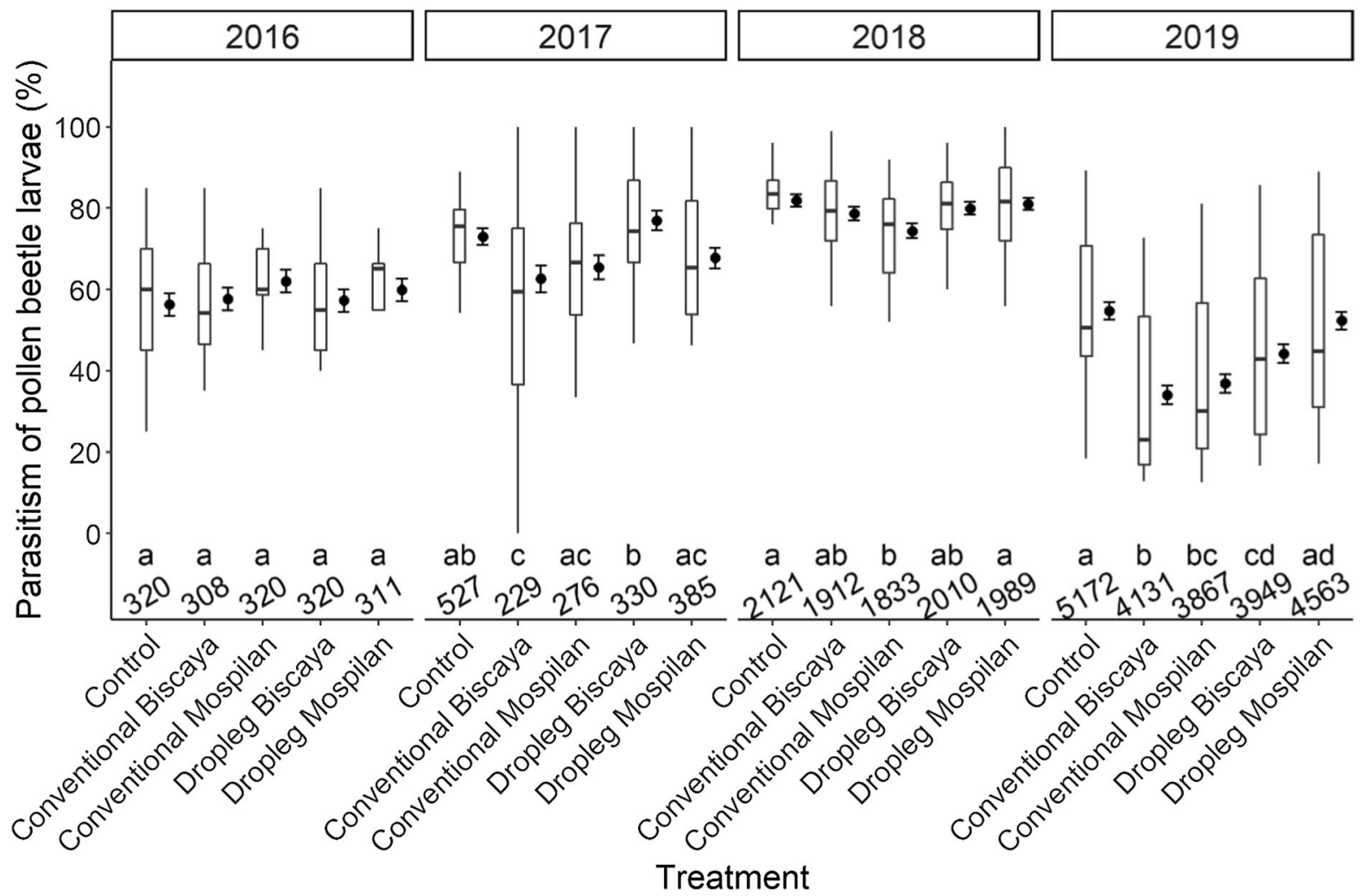

Fig. 4 Boxplots showing the median value (solid line), the 25th and 75th percentile of parasitism rates of pollen beetle larvae by $T$. heterocerus per replicate and sampling date in the years 2016-2019; the error bars below and above the box indicate the 10 th and 90th percentile, respectively. Additional, calculated

distribution (Fig. 2b). The most frequently caught parasitoid species were $T$. heterocerus $(56 \%$ of all parasitoid catches) and $P$. interstitialis $(16 \%$ of all parasitoid catches), both of which parasitize the larvae of $B$. aeneus. The two parasitoid species can avoid competition as $P$. interstitialis parasitizes eggs and $\mathrm{L}_{1}$ larvae in the buds, whereas $T$. heterocerus prefers $\mathrm{L}_{2}$ larvae in the open flowers (Berger et al. 2015; Nilsson 2003). The latter is also known to feed on nectar during flowering of OSR (Rusch et al. 2013). This is in agreement with the vertical distribution pattern of these two parasitoids shown in our study, as $T$. heterocerus was found predominantly in the flowering canopy, while $P$. interstitialis was instead found below flowering canopy on most sampling dates. These findings are in agreement with previous studies, in which parasitoids were caught in yellow water traps that were placed at soil level and at top height of the flowering canopy (Neumann 2010; Nitzsche 1998). means $\pm \mathrm{SE}$ obtained from the best model are shown. Treatments with different letters within a given year differ significantly from each other $(p<0.05)$. Numbers below the boxplots show the total number of larvae investigated per treatment and year

Tersilochus heterocerus was mainly found at top height, while females of $P$. interstitialis were equally distributed at crop height and soil level (Neumann 2010). Overall, these observations fit the niche separation hypothesis (Berger et al. 2015) as both parasitoid species, although competing for the same host, use their environment and resources differently. Based on these results, we hypothesized that the pollen beetle parasitoid $T$. heterocerus should benefit most from the new dropleg technique. Although effects on other parasitoid species have not been assessed in this study, we assume that the $C$. obstrictus parasitoid, $M$. morys, could also benefit from the use of the dropleg technique, because this species was frequently found in the flowering canopy, albeit in low numbers. In contrast, the pollen beetle parasitoid $P$. interstitialis, the chalcid wasp $T$. perfectus, which parasitizes $C$. obstrictus and parasitoids of the stem weevils, were collected mostly below canopy. A positive impact of 
the dropleg application technique on these species seems therefore unlikely.

In four years field trials, we tested the hypothesis that dropleg spraying causes less side-effects on $T$. heterocerus. The rate of pollen beetle larvae parasitized by $T$. heterocerus in the untreated control in all four years exceeded $50 \%$, which is high enough to have a significant impact on pollen beetle population development (Hokkanen 2008; Jansen 2017). The parasitism rates in treatments with dropleg technique never differed from the unsprayed control with the exception of the dropleg Biscaya treatment in 2019, where a significantly lower parasitism rate was found. On the other hand, in 2016-2019, four out of eight insecticide treatments, using conventional spray application, significantly reduced parasitism rates compared to the control.

Since conventional insecticide application greatly reduced the number of pollen beetle larvae in the crop, it is possible that lower host densities could explain the decreased parasitism rates, when compared to the untreated plots. However, other studies found no relationship between host density and parasitism rates in pollen beetle parasitoids (Ferguson et al. 2003; Kaasik et al. 2014). Furthermore, in our control plots we observed no interaction between parasitism rates and larval densities over the four years. Hence, we assume that direct toxic effects of the insecticides on adult parasitoids rather than reduced host density caused lower parasitism rates in the conventional treatments.

Strikingly, the effects of the conventional application in our field trials were quite variable between years and also between the two neonicotinoid insecticides. The persistence of insecticide activity in the field can be affected by environmental conditions such as temperature, air humidity and UV light (Holmstrup et al. 2010). Higher post-exposure temperatures can increase the toxicity of acetamiprid to psyllids and green lacewings (Boina et al. 2009; Mansoor et al. 2015). The differences between the insecticide effects in our study therefore might be related to different temperature regimes in individual years (Fig. 1). In 2018, insecticides were applied in the field trial at 10:00 AM at approximately $20^{\circ} \mathrm{C}$ and the following days were warm and sunny. In 2019, however, the application was carried out in the evening at approx. $16{ }^{\circ} \mathrm{C}$, with low temperatures on the following days (Fig. 1). Such different conditions may possibly explain why Mospilan in 2018 showed a stronger impact on larval parasitoids than Biscaya.

Furthermore, temperature and environmental conditions also determine the time of immigration of parasitoids from their place of emergence into the new crop (Johnen et al. 2010; Nilsson 2003), which was recorded by sampling with a portable aspirator around the dropleg field trials in 2018 and 2019 (Fig. 3a). Tersilochus heterocerus starts to migrate when the average daily temperature exceeds $10{ }^{\circ} \mathrm{C}$, combined with sunshine and a maximum daily temperature above $14{ }^{\circ} \mathrm{C}$ (Johnen et al. 2010). This was the case at the beginning of OSR flowering in both years. In 2018, migration into the field was within a few days and the main period of activity was during full bloom. In the field trial, the insecticides were applied at the peak of T. heterocerus abundance. However, its main activity period started already one week before (Fig. 3a). In contrast, due to lower temperatures (Fig. 1), the flowering period in 2019 was much longer and the abundance of $T$. heterocerus increased only slowly without showing a specific peak. The insecticide application was conducted during the first wave of immigration, leading to a significant reduction of parasitism rates by conventional spraying. In 2018, the average rate of pollen beetle larvae parasitized by $T$. heterocerus was as high as $80 \%$ six days after application. In 2019, parasitism rate was only $24 \%$ at day 9 after application. Thus, the temporal coincidence of insecticide application and an increasing abundance of $T$. heterocerus may have resulted in greater effects in the year 2019 compared to 2018. It is likely that the insecticides did not have any impact in the year 2016, because the warm days preceding the application (Fig. 1) had already allowed the parasitoids to nearly complete egg laying. Similar findings were presented by Brandes et al. (2018), who investigated the effects of insecticide applications during the bud stage (BBCH 55) or the flowering stage (BBCH 62-65) of OSR on parasitism rates of pollen beetle larvae by $T$. heterocerus. The authors were unable to detect larval parasitism by $T$. heterocerus before $\mathrm{BBCH} 65$ and insecticide applications at this growth stage tended to reduce parasitism rates compared to applications at the bud stage (BBCH 55). Overall, the results indicate that the timing of an insecticide application is a major factor influencing the side effects on parasitoids. However, detrimental 
effects of insecticides on $T$. heterocerus were also moderated by using the dropleg technique.

In conclusion, many parasitoid species are abundant in high numbers during the bloom of OSR. The vertical distribution patterns of parasitoid species in the crop showed that many species prefer a specific crop layer, presumably because of niche separation between species based on the distribution of their hosts. Although parasitism rates of pollen beetle larvae varied between years, our data revealed that only in a single year dropleg spraying affected parasitism rates by the most important parasitoid of pollen beetle larvae. This was in contrast to conventional application, which had a stronger detrimental impact on $T$. heterocerus. Whether other parasitoid species might benefit from dropleg application needs further investigation. Additionally, the trade-off between a somewhat lower efficacy of insecticides applied with dropleg technique against pests and the reduced side effects on beneficial parasitoids should be evaluated under real-world farming conditions. Overall, our study suggests that, to some extent, dropleg spray application can reduce non-target effects of neonicotinoid insecticides on the most important parasitoid of pollen beetle.

Acknowledgements The authors would like to thank all the students and research assistants for their work in the field and laboratory. We thank Bernd Ulber (University of Göttingen) who contributed to the work by many helpful suggestions and useful discussions. Also, parasitism levels by Phradis spp. in the years 2016 and 2018 were assessed in the laboratory of Bernd Ulber. We would like to thank the anonymous reviewers for their constructive and helpful comments that improved our manuscript.

Funding Open Access funding enabled and organized by Projekt DEAL. No funding was received for conducting this study.

Data availability Not applicable.

Code availability Not applicable.

\section{Declarations}

Conflict of interest The authors declare that they have no conflicts of interest.

Ethical approval Not applicable.

Open Access This article is licensed under a Creative Commons Attribution 4.0 International License, which permits use, sharing, adaptation, distribution and reproduction in any medium or format, as long as you give appropriate credit to the original author(s) and the source, provide a link to the Creative Commons licence, and indicate if changes were made. The images or other third party material in this article are included in the article's Creative Commons licence, unless indicated otherwise in a credit line to the material. If material is not included in the article's Creative Commons licence and your intended use is not permitted by statutory regulation or exceeds the permitted use, you will need to obtain permission directly from the copyright holder. To view a copy of this licence, visit http://creativecommons.org/licenses/by/4.0/.

\section{References}

Abram PK, Brodeur J, Urbaneja A, Tena A (2019) Nonreproductive effects of insect parasitoids on their hosts. Annu Rev Entomol 64:259-276

Alford DV, Nilsson C, Ulber B (2003) Insect pests of oilseed rape crops. In: Alford DV (ed) Biocontrol of oilseed rape pests. Blackwell Science, Oxford, pp 9-42

Basil G (2002) Drop-Leg, on-target, application improving crop-input application using spray boom attached, droplegs. In: Westerdijk CE, Schepers H (eds) Sixth workshop of an European network for development of an integrated control strategy of potato late blight. Applied Plant Research BV, Wageningen, pp 49-57

Beckmann M, Gerstner K, Akin-Fajiye M, Ceauşu S, Kambach S, Kinlock NL, Phillips HRP, Verhagen W, Gurevitch J, Klotz S, Newbold T, Verburg PH, Winter M, Seppelt R (2019) Conventional land-use intensification reduces species richness and increases production: a global metaanalysis. Glob Change Biol 25:1941-1956

Berger J, Jönsson M, Hedlund K, Anderson P (2015) Niche separation of pollen beetle parasitoids. Front Ecol Evol $3: 45$

Boina DR, Onagbola EO, Salyani M, Stelinski LL (2009) Influence of posttreatment temperature on the toxicity of insecticides against Diaphorina citri (Hemiptera: Psyllidae). J Econ Entomol 102:685-691

Brandes M, Heimbach U, Ulber B (2018) Effects of insecticide application on parasitism rates of pollen beetle larvae (Brassicogethes aeneus (Fabricius)) by tersilochine parasitoids. Arthropod Plant Interact 12:799-809

Burnham KP, Anderson DR (2002) Model selection and multimodel inference: a practical information-theoretic approach. Springer, New York

Dicke D (2018) Vier jahre erfahrung. DLG-Mitteilungen 2018:56-57

European Commission (2020) EU Biodiversity strategy for 2030. Bringing nature back into our lives: COM/2020/380 final. https://ec.europa.eu/info/sites/default/files/ communication-annex-eu-biodiversity-strategy-2030_en. pdf. Accessed 17 May 2021

Ferguson AW, Barari H, Warner DH, Watts NP, Schmidt JE, Williams IH (2003) Spatio-temporal distributions of Meligethes aeneus and its parasitoids in an oilseed rape crop and their significance for crop protection. In: 
Soerensen H, Soerensen JC (eds) Towards enhanced value of cruciferous oilseed crops by optimal production and use of the high quality seed components, 1st edn. Royal Veterinary and Agricultural University, Frederiksberg, pp 1057-1059

Ferguson AW, Williams IH, Castle LM, Skellern M (2010) Key parasitoids of the pests of oilseed rape in Europe: a guide to their identification. In: Williams IH (ed) Biocontrol-based integrated management of oilseed rape pests. Springer, Dordrecht, pp 77-114

Garratt MPD, Coston DJ, Truslove CL, Lappage MG, Polce C, Dean R, Biesmeijer JC, Potts SG (2014) The identity of crop pollinators helps target conservation for improved ecosystem services. Biol Conserv 169:128-135

Habel JC, Segerer A, Ulrich W, Torchyk O, Weisser WW, Schmitt T (2016) Butterfly community shifts over two centuries. Conserv Biol 30:754-762

Hallmann CA, Sorg M, Jongejans E, Siepel H, Hofland N, Schwan H, Stenmans W, Müller A, Sumser H, Hörren T, Goulson D, de Kroon H (2017) More than 75 percent decline over 27 years in total flying insect biomass in protected areas. PLoS ONE 12(10):e0185809

Hatt S, Osawa N (2019) Beyond "greening": which paradigms shape sustainable pest management strategies in the European Union? BioControl 64:343-355

Hausmann J, Brandes M, Heimbach U (2019) Effects of dropleg application technique during flowering of oilseed rape on insect pests. Crop Prot 126:104917

Hayter KE, Cresswell J (2006) The influence of pollinator abundance on the dynamics and efficiency of pollination in agricultural Brassica napus: implications for landscapescale gene dispersal. J Appl Ecol 43:1196-1202

Heimbach U, Müller A (2013) Incidence of pyrethroid-resistant oilseed rape pests in Germany. Pest Manage Sci 69:209-216

Hervé MR, Garcia N, Trabalon M, Le Ralec A, Delourme R, Cortesero AM (2015) Oviposition behavior of the pollen beetle (Meligethes aeneus): a functional study. J Insect Behav 28:107-119

Hokkanen HMT (2008) Biological control methods of pest insects in oilseed rape. EPPO Bull 38:104-109

Holmstrup M, Bindesbøl A-M, Oostingh GJ, Duschl A, Scheil V, Köhler H-R, Loureiro S, Soares AMVM, Ferreira ALG, Kienle C, Gerhardt A, Laskowski R, Kramarz PE, Bayley M, Svendsen C, Spurgeon DJ (2010) Interactions between effects of environmental chemicals and natural stressors: a review. Sci Total Environ 408:3746-3762

IRAC (2019) Pollen beetle resistance monitoring 2018. https:// irac-online.org/pests/meligethes-aeneus/. Accessed 17 Aug 2020

IRAC (2020) Mode of action classification scheme. https://iraconline.org/documents/moa-classification/. Accessed 21 May 2021

Jansen J-P (2017) A large field trial to assess the short-term and long-term effects of several 4 insecticides used to control the pollen beetle on parasitic hymenoptera in oilseed rape. IOBC/WPRS Bull 125:1-9

Johnen A, Williams IH, Nilsson C, Klukowski Z, Luik A, Ulber B (2010) The proPlant decision support system: phenological models for the major pests of oilseed rape and their key parasitoids in Europe. In: Williams IH (ed) Biocontrol- based integrated management of oilseed rape pests. Springer, Dordrecht, pp 381-403

Kaasik R, Kovács G, Kaart T, Metspalu L, Williams IH, Veromann E (2014) Meligethes aeneus oviposition preferences, larval parasitism rate and species composition of parasitoids on Brassica nigra, Raphanus sativus and Eruca sativa compared with on Brassica napus. Biol Control 69:65-71

Karise R, Raimets R, Bartkevics V, Pugajeva I, Pihlik P, Keres I, Williams IH, Viinalass H, Mänd M (2017) Are pesticide residues in honey related to oilseed rape treatments? Chemosphere 188:389-396

Kovács G, Kaasik R, Lof ME, van der Werf W, Kaart T, Holland JM, Luik A, Veromann E (2019) Effects of land use on infestation and parasitism rates of cabbage seed weevil in oilseed rape. Pest Manage Sci 75:658-666

Lancashire PD, Bleiholder H, van den Boom T, Langelüddeke P, Stauss R, Weber E, Witzenberger A (1991) A uniform decimal code for growth stages of crops and weeds. Ann Appl Biol 119:561-601

Lechler (2020) Dropleg UL. https://www.lechler.com/ fileadmin/media/datenblaetter/agrar/lechler_agrar_ zubehoer_dropleg.pdf. Accessed 5 Feb 2020

Lenth R, Love J, Herve M (2018) emmeans: estimated marginal means, aka least squares means. https://cran.r-project.org/ package=emmeans. Accessed 31 July 2021

Mansoor MM, Afzal M, Raza ABM, Akram Z, Waqar A, Afzal MBS (2015) Post-exposure temperature influence on the toxicity of conventional and new chemistry insecticides to green lacewing Chrysoperla carnea (Stephens) (Neuroptera: Chrysopidae). Saudi J Biol Sci 22:317-321

Muller FJ, Baur H, Gibson GA, Mason PG, Kuhlmann U (2007) Review of the species of Trichomalus (Chalcidoidea: Pteromalidae) associated with Ceutorhynchus (Coleoptera: Curculionidae) host species of European origin. Can Entomol 139:643-657

Murchie AK, Williams IH, Alford DV (1997) Effects of commercial insecticide treatments to winter oilseed rape on parasitism of Ceutorhynchus assimilis Paykull (Coleoptera: Curculionidae) by Trichomalus perfectus (Walker) (Hymenoptera: Pteromalidae). Crop Prot 16:199-202

Neumann N (2010) Lethal and sublethal effects of insecticides on mortality, migration and host searching behaviour of tersilochine parasitoids on winter oilseed rape. $\mathrm{PhD}$ dissertation, Georg-August-Universität Göttingen

Nilsson C (2003) Parasitoids of pollen beetles. In: Alford DV (ed) Biocontrol of oilseed rape pests. Blackwell Science, Oxford, pp 73-86

Nissen U (1997) Ökologische studien zum auftreten von schadinsekten und ihren parasitoiden an winterraps norddeutscher anbaugebiete. PhD dissertation, Christian-Albrechts-Universität

Nitzsche O (1998) Auftreten und effizienz von parasitoiden als natürliche gegenspieler von schadinsekten im winterraps unter besonderer berücksichtigung unterschiedlicher bodenbearbeitungsmaßnahmen nach winterraps. $\mathrm{PhD}$ dissertation, Georg-August-Universität

R Core Team (2019) R: a language and environment for statistical computing, Vienna, Austria. https://www.r-project. org. Accessed 21 July 2021 
Rosenkranz P, Ohe W von der, Schäfer M, Genersch E, Büchler R, Berg S, Otten C (2019) Zwischenbericht 2018 deutsches bienenmonitoring_- "DeBiMo". https://bienenmonitoring. uni-hohenheim.de/fileadmin/einrichtungen/ bienenmonitoring/Dokumente/Zwischenbericht_ DeBiMo_2018.pdf. Accessed 5 Oct 2020

Rüegg J, Total R (2013) Dropleg-application technique for better targeted sprays in row crops. https://ira.agroscope. ch/en-US/Page/Publikation?einzelpublikationId=32887. Accessed 14 Aug 2021

Rusch A, Suchail S, Valantin-Morison M, Sarthou J-P, RogerEstrade J (2013) Nutritional state of the pollen beetle parasitoid Tersilochus heterocerus foraging in the field. BioControl 58:17-26

Tayo TO, Morgan DG (1975) Quantitative analysis of the growth, development and distribution of flowers and pods in oil seed rape (Brassica napus L.). J Agric Sci 85:103-110

Ulber B, Klukowski Z, Williams IH (2010a) Impact of insecticides on parasitoids of oilseed rape pests. In: Williams IH (ed) Biocontrol-based integrated management of oilseed rape pests. Springer, Dordrecht, pp 337-355

Ulber B, Williams IH, Klukowski Z, Luik A, Nilsson C (2010b) Parasitoids of oilseed rape pests in Europe: key species for conservation biocontrol. In: Williams IH (ed) Biocontrolbased integrated management of oilseed rape pests. Springer, Dordrecht, pp 45-76

van Reeth C, Caro G, Bockstaller C, Michel N (2018) Current and previous spatial distributions of oilseed rape fields influence the abundance and the body size of a solitary wild bee, Andrena cineraria, in permanent grasslands. PLoS ONE 13(5):e0197684

Veromann E, Williams IH, Kaasik R, Luik A (2010) Potential of parasitoids to control populations of the weevil Ceutorhynchus obstrictus (Marsham) on winter oilseed rape. Int J Pest Manage 57:85-92

Vidal S (2003) Identification of hymenopterous parasitoids associated with oilseed rape pests. In: Alford DV (ed) Biocontrol of oilseed rape pests. Blackwell Science, Oxford, pp 161-179

Wallner K (2014) Dropleg UL_die bienenfreundliche düse [Dropleg UL_a bee friendly nozzle]. https://www. magazin-innovation.de/export/sites/magazin-innovation.
de/extras/dokumente/Innovation-ab-4-13/2-14-dropleg-ul. pdf. Accessed 12 Aug 2021

Wallner K (2015) Rapsbestand mit düsen durchkämmen. Land Forst 168:14-16

Weimar-Bosse C, von Hörsten D, Heimbach U (2017) Bericht über den "Workshop zu möglichkeiten und herausforderungen der anwendung der droplegtechnologie im raps" [Proceedings of the workshop on the use of dropleg technique in oilseed rape]. J Kulturpflanzen 69:113

Westphal C, Steffan-Dewenter I, Tscharntke T (2003) Mass flowering crops enhance pollinator densities at a landscape scale. Ecol Lett 6:961-965

Westphal C, Steffan-Dewenter I, Tscharntke T (2009) Mass flowering oilseed rape improves early colony growth but not sexual reproduction of bumblebees. J Appl Ecol 46:187-193

Wickham H (2016) ggplot2: elegant graphics for data analysis. Use R! Springer, Cham

Williams IH (2010) The major insects pests of oilseed rape in Europe and their management: an overview. In: Williams IH (ed) Biocontrol-based integrated management of oilseed rape pests. Springer, Dordrecht, pp 1-43

Johannes Hausmann This research is part of a $\mathrm{PhD}$ project of Johannes Hausmann devoted to control strategies of insect pests in flowering oilseed rape. A focus is the evaluation of dropleg application technique with regard to its efficacy against pest insects and possible effects on parasitoids.

Udo Heimbach was a scientist at the Julius Kühn-Institut and worked with insect pests of oilseed rape.

Michael Rostás is head of the agricultural entomology section at the Georg-August-Universität Göttingen, Germany. A focus of his work are chemo-ecological interactions between insects, microorganisms and crops.

Meike Brandes This work was carried out in the entomology working group on insect pests of oilseed rape of Dr. Meike Brandes at the Julius Kühn-Institut, Institute for Plant Protection in Field Crops and Grassland, Braunschweig, Germany. 